\title{
ÜNIVERSITEPARK Bülten
}

ISSN 2147- 351X (Print)

\section{ÜNIVERSITEPARK Bülten • Volume 2・Issue 2 • 2013}

Olimpiyat Şampiyonu Aslı Çakır Alptekin ÜNiVERSiTEPARK Bülten'in Onur Konuğu Oldu

\section{Turgut Karaköse}

To cite this article: Karaköse, T. (2013). Olimpiyat Şampiyonu Aslı Çakır Alptekin Üniversitepark Bülten'in Onur Konuğu Oldu. Üniversitepark Bülten, 2(2), 4-9.

Note: Open Access starting with Vol. 3, Issue 1-2/2014. In order to access full text of this manuscript, please contact Editor-in-Chief at editor@unibulletin.com 